\title{
PERAN SISTEM PENJAMINAN MUTU PENDIDIKAN DALAM MENINGKATKAN MUTU PENDIDIKAN DI MADRASAH
}

\author{
Khoirul Anwar1)* \\ 1 Program Studi Pendidikan Agama Islam, \\ Universitas Islam Sultan Agung (UNISSULA) Semarang \\ *E-mail: khoirul@unissula.ac.id
}

\begin{abstract}
The quality of education is related to whether or not national education goals are achieved as stated in Law No. 20 of 2003 concerning the National Education System. Therefore, the quality of education can be said it is good if it meets the National Education Standards. The fulfillment of minimum standards of education which is the National Standard of Education is a prerequisite to improve the quality of education including madrasah. The reality that emerges is the quality of education in Indonesia is still far from what is expected, let a quality in most madrasah which are still having many obstacles. Many madrasah do not qualify the National Education Standards, such as educators and education staff who have not met standardized qualifications and competencies, and inadequate facilities and infrastructure. This paper aims to describe how the role of the education quality assurance system in improving the quality of education in madrasah.
\end{abstract}

Keywords: Quality of Education, Madrasah, National Education Standards

\begin{abstract}
Abstrak
Mutu pendidikan berkaitan dengan tercapai atau tidaknya tujuan pendidikan nasional seperti yang tercantum di dalam UU No. 20 Tahun 2003 tentang Sistem Pendidikan Nasional. Oleh karena itu, mutu pendidikan dapat dikatakan baik apabila memenuhi Standar Nasional Pendidikan. Terpenuhinya standar minimal pendidikan yang merupakan Standar Nasional Pendidikan merupakan prasyarat untuk meningkatkan mutu pendidikan termasuk madrasah. Realitas yang muncul bahwa mutu pendidikan di Indonesia masih cukup jauh dari yang diharapkan, apalagi mutu di kebanyakan madrasah yang masih banyak mengalami kendala. Banyak madrasah yang belum memenuhi Standar Nasional Pendidikan, seperti tenaga pendidik dan kependidikan yang belum memenuhi kualifikasi dan kompetensi yang distandarkan, serta sarana dan prasarana yang belum memadai. Tulisan ini bertujuan untuk mendeskripsikan bagaimana peran sistem pejaminan mutu pendidikan dalam meningkatkan mutu pendidikan di madrasah.
\end{abstract}

Kata Kunci: Mutu Pendidikan, Madrasah, Standar Nasional Pendidikan

\section{PENDAHULUAN}

Masalah mutu pendidikan merupakan salah satu isu sentral dalam pendidikan nasional, terutama berkaitan dengan rendahnya mutu pendidikan pada setiap jenjang dan satuan pendidikan, terutama pada jenjang pendidikan dasar dan menengah. Menyadari hal tersebut, Pemerintah telah melakukan berbagai upaya untuk meningkatkan mutu pendidikan nasional. Meskipun demikian, berbagai indikator mutu pendidikan mengindikasikan bahwa berbagai upaya yang telah dilakukan 
pemerintah belum menunjukkan hasil yang memuaskan, dan belum menunjukkan peningkatan yang berarti. Sebagian sekolah, terutama di kota-kota, menunjukkan peningkatan mutu pendidikan yang cukup menggembirakan, namun sebagian besar lainnya masih cukup memprihatinkan.

Usaha untuk meningkatkan mutu pendididkan di negeri ini telah lama diupayakan. Sejak Indonesia merdeka sampai di era informasi sekarang ini, peningkatan mutu pendidikan merupakan salah satu prioritas pembangunan di bidang pendidikan. Berbagai inovasi dan program pendidikan juga telah ditempuh. Penyempurnaan kurikulum, pengadaan bahan ajar, buku paket, pengadaan sarana, dan termasuk peningkatan mutu guru.

Upaya tersebut dilakukan karena pendidikan bermutu merupakan harapan bagi bangsa ini. Pendidikan diharapkan dapat melahirkan manusia Indonesia seutuhnya, sebagaimana terdapat dalam perundangan yang berlaku. Pendidikan yang bermutu harus disediakan melalui jalur, jenis, dan jenjang yang ada dalam sistem pendidikan kita, termasuk pendidikan madrasah. Pendidikan yang bermutu dapat terselenggara dengan komitmen bersama antara pemerintah, masyarakat, dan keluarga. Pendidikan bermutu pada setiap jenis, jenjang dan jalur pendidikan harus dapat diakses oleh seluruh warga Indonesia.

Mutu pendidikan berkaitan dengan tercapai atau tidaknya tujuan pendidikan nasional seperti yang tercantum di dalam UU No. 20 Tahun 2003 tentang Sistem Pendidikan Nasional. Selain itu, mutu pendidikan dapat dikatakan baik apabila memenuhi Standar Nasional Pendidikan. Terpenuhinya standar minimal pendidikan yang merupakan Standar Nasional Pendidikan merupakan prasyarat untuk meningkatkan mutu pendidikan termasuk madrasah (Syukran, 2010: 43).

Sejak lahirnya UU No. 20 Tahun 2003 tersebut yang diikuti oleh PP No. 19 Tahun 2005, Madrasah memiliki kedudukan yang sama dengan sekolah umum. Oleh karena itu, peningkatan mutu madrasah harus dilaksanakan seiring dengan Undang-undang dan Peraturan pemerintah tersebut. Demikian ini karena kiprah madrasah sangat besar dan telah memberikan kontribusi dalam pendidikan nasional di Indonesia. Ia tetap eksis di tengah keterbatasan dan telah turut berpartisipasi dalam mencerdaskan kehidupan bangsa.

Sebagai salah satu lembaga pendidikan Islam yang mengakar di masyarakat, madrasah adalah manifestasi kebudayaan bangsa Indonesia yang harus dirawat dan 
dikembangkan. Sebab tidak dapat dipungkiri bahwa lembaga ini telah berjasa besar, khususnya dalam mencerdaskan kehidupan bangsa Indonesia. Madrasah juga telah melahirkan nasionalis sejati yang aktif memperjuangkan kemerdekaan bangsa dari belenggu kolonial yang telah berabad-abad menjajah negeri ini (Makmur, 2013: 11).

Madrasah, baik Madrasah Ibtidaiyah (MI), Madrasah Tsanawiyah (MTs), maupun Madrasah Aliyah (MA) dengan sekitar 92\% masih berstatus swasta, dan umumnya berada di tengah masyarakat pedesaan atau di sekitar pinggiran kota, memiliki andil sangat besar dalam ikut menggalang masyarakat menuntaskan wajib belajar 9 tahun (Umar, 2016: xiii). Meski demikian, diakui bahwa di tengah peran penting madrasah dalam mendidik bangsa ini, masih banyak persoalan yang membelitnya, khususnya yang berkaitan dengan mutu pendidikan di madrasah.

Realitas yang muncul bahwa mutu pendidikan di Indonesia masih cukup jauh dari yang diharapkan, apalagi mutu pendidikan di kebanyakan madrasah yang masih banyak mengalami kendala. Banyak madrasah yang belum memenuhi Standar Nasional Pendidikan, seperti tenaga pendidik dan kependidikan yang belum memenuhi kualifikasi dan kompetensi yang distandarkan, serta sarana dan prasarana yang belum memadai.

Selama ini madrasah dianggap sebagai lembaga pendidikan Islam yang mutunya lebih rendah daripada mutu lembaga pendidikan lainnya, terutama sekolah umum, walaupun beberapa madrasah justru lebih maju daripada sekolah umum. Namun keberhasilan beberapa madrasah dalam jumlah yang terbatas itu belum mampu menghapus kesan negatif "sekolah mutu rendah" yang sudah terlanjur melekat selama ini (Qomar, 2009:80).

Memang upaya peningkatan mutu pendidikan saat ini sudah menjadi komitmen bersama dari seluruh rakyat Indonesia, termasuk peningkatan mutu pendidikan pada madrasah. Namun dalam kenyataannya masih banyak madrasah yang belum memenuhi standar mutu yang diharapkan. Implementasi mutu memiliki dua aspek utama, yaitu produknya memenuhi tuntutan pelanggan. Kedua, produk sesuai dengan standar (Makbuloh, 2016:32). Berdasarkan deskripsi di atas, maka tulisan ini akan membahas tentang peran sistem penjaminan mutu pendidikan dalam meningkatkan mutu pendidikan di madrasah. 


\section{PEMBAHASAN}

\section{Hakikat Mutu Pendidikan}

Secara umum, mutu dapat diartikan sebagai gambaran dan karaktersitik menyeluruh dari barang atau jasa yang menunjukkan kemampuannya dalam memuaskan kebutuhan yang diharapkan atau yang tersirat. Dalam konteks pendidikan, pengertian mutu mencakup input, proses, dan output pendidikan (Mulyasa, 2012:157).

Dewasa ini semua lembaga pendidikan, termasuk madrasah berorientasi pada mutu. Lembaga pendidikan dikatakan "bermutu" jika input, proses dan output-nya dapat memenuhi persyaratan yang dituntut oleh pengguna jasa pendidikan. Bila performance-nya dapat melebihi persyaratan yang dituntut oleh stakeholder (user), maka suatu lembaga pendidikan baru dapat dikatakan unggul. Lantaran tuntutan persyaratan kualitas yang dikehendaki para user terus berubah dan berkembang, maka pengertian mutu juga bersifat dinamis dan terus berkembang (Qomar, 2009: 206).

Mutu adalah kemampuan (ability) yang dimiliki oleh satuan produk atau jasa (services), yang dapat memenuhi kebutuhan atau harapan kepuasan (satisfaction) pelanggan (customers). Dalam dunia pendidikan, pelanggan dikelompokkan menjadi dua, yaitu internal customer dan external customer. Internal customer yaitu siswa atau mahasiswa sebagai pembelajar (learners), dan external customer yaitu masyarakat dan dunia industri.

Mutu tidak lahir dan berdiri sendiri, melainkan melibatkan banyak faktor untuk kelahirannya. Di antara yang terlibat tersebut adalah sistem penjaminan mutu (Quality Assurance System). Sistem inilah yang akan mengawal mutu lembaga pendidikan, termasuk pendidikan di madrasah. Dan sistem ini pulalah yang akan bertanggung jawab mendistribusikan output lembaga pendidikan.

Penjaminan mutu (Quality Assurance) merupakan istilah yang digunakan untuk mewakili kegiatan monitoring, evaluasi, atau kajian (review) mutu. Kegiatan penjaminan mutu tertuju pada proses untuk membangun kepercayaan, dengan cara melakukan pemenuhan persyaratan atau standar minimum pada komponen input, komponen proses, dan hasil atau outcome, sesuai dengan yang diharapkan oleh stake holders. Dalam bidang pendidikan, penjaminan mutu merupakan cara mengatur semua kegiatan dan sumber daya pendidikan yang diarahkan pada kepuasan pelanggan (Mahmud, 2012: 13). 
Penjaminan mutu memiliki dua bentuk, yaitu pertama, desain kegiatan proses perbaikan dan pengembangan mutu secara berkelanjutan (continuous quality culture). Di dalamnya terkandung tata nilai (values) yang menjadi keyakinan stake holders pendidikan, serta prinsip maupun asas-asas yang dianutnya. Dengan demikian, penjaminan mutu sebagai sebagai suatu sistem mengandung tata nilai dan asas dalam proses perubahan, perbaikan dan peningkatan mutu secara berkelanjutan.

Penjaminan mutu pendidikan diatur dalam Peraturan Menteri Pendidikan Nasional Nomor 63 Tahun 2009 tentang Sistem Penjaminan Mutu Pendidikan. Penjaminan mutu, dalam peraturan tersebut, didefinisikan sebagai kegiatan yang sistemik dan terpadu pada penyelenggaraan pendidikan untuk meningkatkan tingkat kecerdasan kehidupan bangsa. Kegiatan yang sistemik terpadu tersebut dilakukan oleh satuan atau program pendidikan, penyelenggara satuan/program pendidikan, pemerintah daerah, pemerintah, masyarakat, serta melibatkan dunia usaha.

Untuk menciptakan pendidikan yang bermutu sebagaimana yang diharapkan banyak orang atau masyarakat bukan hanya menjadi tanggung jawab sekolah, tetapi merupakan tanggung jawab semua pihak, termasuk di dalamnya orang tua dan dunia usaha sebagai customer internal dan eksternal dari sebuah lembaga pendidikan. Arcaro S Jerome sebagaimana dikutip oleh (Rivai, 2016:118) menyampaikan bahwa terdapat lima karakteristik sekolah yang bermutu yaitu: Fokus pada pelanggan, keterlibatan total, pengukuran, komitmen dan perbaikan berkelanjutan

Pelaksanaan penjaminan mutu pendidikan terutama berada pada satuan/program pendidikan. Penyelenggara satuan program pendidikan berkewajiban menyediakan dan memberikan bantuan dalam pemenuhan standar. Pemerintah kabupaten/kota, pemerintah propinsi, melakukan pengawasan, evaluasi, fasilitasi, memberikan saran arahan dan/atau bimbingan kepada satuan/program pendidikan. Kesalingterkaitan antar komponen tersebut menuntut adanya desain yang jelas. Desain yang menjelaskan tugas dan kewenangan antar komponen, untuk penjaminan mutu pendidikan. Grand desain ini disusun berdasarkan masukan berbagai pemangku kepentingan (stakeholder) pendidikan yang kemudian ditetapkan sebagai standar mutu.

Penetapan standar mutu pendidikan memerlukan berbagai pendekatan berbasis standar (standard based approach). Hal ini diperlukan untuk mengukur dan menilai pemenuhan standar yang telah ditetapkan dalam kebijakan mutu. Pendekatan 
berbasis standar ini telah banyak digunakan oleh berbagai Negara di Amerika Serikat dan di Eropa oleh Badan Akreditasi Pendidikan dalam mengukur pencapaian standar mutu minimum atau standar pelayanan minimum.

Secara kelembagaan, sistem penjaminan mutu pendidikan diposisikan sebagai bagian dari keseluruhan fungsi dari manajemen pendidikan. Sistem penjaminan mutu pendidikan sebagai salah satu fungsi manajemen pendidikan, mengemban tugas dan tanggung jawab dalam mengukur dan menilai pemenuhan standar mutu, sebagaimana yang telah ditetapkan dalam kebijakan atau regulasi.

Sistem penjaminan mutu pendidikan dalam kegiatan, fokus terhadap peningkatan mutu secara berkelanjutan, dengan cara mengukur dan menilai mutu sistem pendidikan, kinerja institusi pendidikan, dan mutu program studi. Sistem penjaminan mutu pendidikan dapat dipandang sebagai instrument kebijakan dalam mengefektifkan implementasu kebijakan, untuk mencapai akuntabilitas sesuatu pendidikan terhadap masyarakat atau publik.

Oleh karena itu, di berbagai Negara, termasuk Indonesia menjadikan akreditasi sebagai salah satu cara atau metode yang digunakan dalam sistem penjaminan mutu pendidikan, dan manajemen mutu secara keseluruhan. Di Indonesia, akreditasi dilakukan untuk menentukan kelayakan program, dan satuan pendidikan pada jalur pendidikan formal dan non-formal, pada setiap jenjang dan jenis (Pasal 60 PP Nomor 19/2005) melalui pendekatan audit, pengukuran, dan evaluasi yang dilakukan oleh Badan Akreditasi Nasional (BAN).

\section{Madrasah Sebagai Lembaga Pendidikan Islam}

Madrasah secara bahasa berasal dari akar kata bahasa Arab "darasa" yang berarti belajar. Sedangkan madrasah sendiri berarti tempat belajar atau sekolah formal. Pengertian yang biasa orang awam gunakan untuk madrasah adalah lembaga pendidikan Islam tingkat dasar dan menengah, baik yang mengajarkan ilmu agama Islam saja, perpaduan antara ilmu agama Islam dan ilmu umum, maupun ilmu-ilmu umum yang berbasis ajaran Islam (Nata, 2012:204).

Sebagai lembaga pendidikan Islam di Indonesia, madrasah muncul dan berkembang seiring dengan masuk dan berkembangnya Islam di Indonesia. Seiring dengan perkembangan bangsa Indonesia, madrasah telah mengalami perkembangan, baik dari jenjangnya maupun dari jenisnya semenjak masa kesultanan, masa penjajahan, dan masa kemerdekaan, 
Pertumbuhan dan perkembangan madrasah di Indonesia dipengaruhi tradisi madrasah di Timur Tengah modern yang sudah mengajarkan ilmu-ilmu agama dan umum. Sebelum abad ke-20, tradisi pendidikan Islam di Indonesia belum mengenal istilah madrasah, yang ada hanya pengajian Al-Qur'an di masjid, mushala, pesantren, surau, dan langgar. Istilah madrasah baru menjadi fonemena pada awal abad ke-20, ketika di beberapa wilayah terutama di Jawa dan Sumatera berdiri madrasah.

Selain terpengaruh gagasan madrasah di Timur Tengah, madrasah juga mengadopsi sistem pendidikan kolonial Belanda. Pada masa-masa awal, madrasah didirikan oleh organisasi-organisasi modernis Islam. Misalnya Jami'at Khoir, Al-Irsyad dan Muhammadiyah. Selaras dengan itu, Muhammadiyah mengadopsi sistem kelembagaan pendidikan Belanda secara konsisten dan menyeluruh, dengan mendirikan sekolah-sekolah umum model Belanda. Hanya saja, dimasukkan pendidikan agama (istilah Muhammadiyah metode Qur'an) ke dalam kurikulumnya.

Pertumbuhan madrasah menunjukkan respon progresif dan defensive umat Islam. Progresif dalam merespon kemajuan organisasi dan penyelenggaraan pendidikan, serta defensive terhadap politik pendidikan Hindia Belanda pada saat itu. Setelah Indonesia merdeka, perhatian terhadap madrasah atau pendidikan Islam terus berlanjut. Hal ini dibuktikan dengan maklumat Badan Pekerja Komite Nasional Indonesia Pusat (BPKNIP), tanggal 22 Desember 1945 (Berita RI tahun II No.4 dan 5 halaman 20 kolom erl). Di dalamnya terdapat penegasan bahwa "Dalam memajukan pendidikan dan pengajaran, sekurang-kurangnya dianjurkan pengajaran di langgar, surau, masjid dan madrasah berjalan terus dan ditingkatkan" (Umar, 2016: 65).

Sebagai tindak lanjut dari maklumat di atas, pada tanggal 27 Desember 1945, BPKNIP menyarankan agar madrasah mendapatkan perhatian dan bantuan materiil dari dari pemerintah. Karena madrasah pada hakikatnya adalah salah satu alat dan sumber pendidikandan pencerdasan rakyat yang sudah mengakar di masyarakat.

Perhatian pemerintah terhadap madrasah semakin besar. Demikian ini dibuktikan dengan berdirinya Kementerian Agama (Kemenag) yang resmi berdiri pada tanggal 3 Januari 1946. Di dalam struktur organisasi Kemenag, terdapat bagian C, yaitu bagian pendidikan dengan tugas pokok mengurus masalah-masalah pendidikan agama di sekolah umum, dan pendidikan agama di sekolah agama (madrasah dan pondok pesantren). 
Pada masa-masa awal Orde Baru, kebijakan mengenai madrasah pada dasarnya bersifat melanjutkan dan memperkuat kebijakan lama. Pada tahap ini, madrasah belum dipandang sebagai bagian dari system pendidikan nasional, tetapi merupakan lembaga pendidikan di bawah menteri agama. Penyebabnya karena pendidikan madrasah lebih didomonasi muatan-muatan agama, dan strukturnya tidak seragam, serta manajemennya yang masih lemah.

Usaha-usaha memasukkan madrasah ke dalam sistem pendidikan nasional, melalui jalan panjang dan berliku. Tantangannya datang dari dalam dan luar Islam. Tantangan dari luar adalah upaya kongruensi yang manyatakan madrasah harus dikelola Kementerian Pendidikan dan Kebudayaan, sebagai satu-satunya departemen yang bertanggung jawab terhadap penyelenggaraan pendidikan nasional. Hal ini ditolak oleh umat Islam yang lebih menghendaki madrasah berada di bawah Kementerian Agama.

Tantangan lain adalah lahirnya Keputusan Presiden Nomor 34 tahun 1972, yang diperkuat dengan Instruksi Presiden Nomor 15 tahun 1974. Isinya dianggap melemahkan dan mengasingkan madrasah dari sistem pendidikan nasional. Sebagian umat Islam memandang Kepres dan Inpres itu sebagai manuver untuk mengabaikan peran dan manfaat madrasah yang sejak zaman penjajahan telah diselenggarakan umat Islam. Situasi ini tak ayal menimbulkan reaksi keras dari umat Islam, khususnya yang menginginkan agar madrasah dapat menjadi bagian dari sistem pendidikan nasional.

Munculnya reaksi keras umat Islam ini disadari oleh pemerintah Orde Baru. Berkaitan dengan Kepres 34/1972 dan Inpres 15/1974, pemerintah kemudian mengambil kebijakan yang lebih bersahabat terkait dengan keberadaan madrasah melalui "pembinaan mutu pendidikan madrasah".

Sejalan dengan upaya peningkatan mutu pendidikan madrasah tersebut, lahirlah Surat Keputusan Bersama (SKB) tiga menteri tanggal 24 Maret 1975, yang ditandatangani Menteri Agama, Menteri Pendidikan dan Kebudayaan serta Menteri Dalam Negeri. Kelahiran SKB Tiga Menteri ini, memang antara lain untuk mengatasi kekhawatiran dan kecemasan umat Islam, akan dihapuskannya sistem pendidikan madrasah sebagai konsekuensi Kepres dan Inpres di atas. 
Kelahiran SKB Tiga Menteri dapat dipandang sebagai model solusi ganda. Di satu sisi sebagai pengakuan terhadap eksistensi madrasah, dan di sisi lain memberikan kepastian kelanjutan pembentukan sistem pendidikan nasional yang integratif.

Meskipun demikian, bukan berarti SKB Tiga Menteri ini tanpa masalah. Bertambahnya beban kurikulum adalah salah satunya. Hal ini sebagai konsekuensi komposisi kurikulum madrasah harus sama dengan sekolah umum, lalu ditambah mata pelajaran Agama Islam yang banyak dan variatif. Padahal di satu pihak, madrasah harus memperbaiki mutu pendidikan umumnya setaraf dengan standar yang berlaku di sekolah. Di lain pihak, bagaimanapun juga madrasah sebagai lembaga Pendidikan Islam harus menjaga mutu pendidikan agamanya.

\section{Penjaminan Mutu di Madrasah}

Berbagai usaha dilakukan oleh pemerintah untuk meningkatkan mutu pendidikan. Pemerintah, dalam hal ini Menteri pendidikan telah mencanangkan "Gerakan Peningkatan Mutu Pendidikan" pada tanggal 2 Mei 2002, dan lebih fokus lagi setelah adanya UU No. 20 tahun 2003 pasal 35 dan PP No.19 tahun 2005 tentang Standar Nasional Pendidikan (Hidayah, 2016: 43).

Lahirnya Undang-Undang Nomor 20 tahun 2003 tentang Sistem Pendidikan Nasional, menempatkan madrasah sejajar dengan lembaga pendidikan lain. Bukan saja kedudukannya yang diakui, melainkan peran penjaminan mutu pendidikan pun dibebankan kepada madrasah. Hal tersebut jelas dalam amanat Bab IV Pasal 5, misalnya. Pada bab dan pasal tersebut, dijelaskan bahwa "Setiap warga Negara mempunyai hak yang sama untuk memperoleh pendidikan yang bermutu" (UUSPN, 2006: 77).

Undang-Undang tersebut dikuatkan oleh Peraturan Pemerintah Nomor 19 tahun 2005 Tentang Standar Nasional Pendidikan. Pada Bab XV Pasal 91 ditegaskan bahwa "Setiap satuan pendidikan pada jalur formal dan non-formal, wajib melakukan penjaminan mutu pendidikan". Penjaminan mutu pendidikan sebagaimana dimaksud, bertujuan untuk memenuhi atau melampaui Standar Nasional Pendidikan (Kompilasi Perundangan Bidang Pendidikan, 2009: 228).

Lahirnya produk hukum tersebut, telah memberikan harapan segar kepada para pengelola dan penyelenggara pendidikan di madrasah. Madrasah yang dinakhodai Kementerian Agama, memiliki peluang dan kesempatan yang sama dengan lembaga pendidikan yang dikelola oleh kementerian Pendidikan. Sebagaimana 
lembaga pendidikan yang lain, madrasah juga bertujuan untuk memberikan layanan pendidikan yang bermutu dalam rangka membangun Sumber Daya Manusia Indonesia yang memiliki kecerdasan spiritual, intelektual, emosional, estetis, kinestetis, serta kecerdasan sosial.

Lahirnya PP Nomor 17 Tahun 2010 tentang Pengelolaan Pendidikan, dan PP Nomor 55 Tahun 2007 tentang Pendidikan Agama dan Keagamaan, memberikan peluang yang besar kepada Kementerian Agama, untuk mengoptimalkan potensi dan sumber daya madrasah. Selain itu, tidak dapat dipungkiri bahwa kepercayaan masyarakat cukup tinggi terhadap madrasah. Itu semua bukan saja karena fungsinya dalam pengembangan intelektual peserta didik semata, akan tetapi ekspektasi tersebut terletak pada penanaman nilai-nilai agama.

Hanya saja kepercayaan tersebut belum sepenuhnya berbanding lurus dengan mutu pelayanan yang diberikan madrasah. Secara umum, madrasah masih dihadapkan pada beberapa kendala yang mempengaruhi mutu proses, dan mutu hasil pendidikan. Latar belakang peserta didik dan keluarganya, dukungan berbagai sumber pendidikan dan kualifikasi pendidikan guru, adalah beberapa kendala tersebut.

Banyak faktor yang diduga menjadi penyebab masih perlunya peningkatan mutu madrasah. Misalnya persoalan manajemen kepemimpinan madrasah, proses pembelajaran, kualitas lulusan, dan belum memadainya sarana dan prasarana pendidikan di madrasah. Berbagai upaya yang telah dilakukan pemerintah untuk meningkatkan mutu pendidikan hingga kini masih menemui banyak tantangan dan belum begitu menggembirakan, bahkan masih banyak kegagalan. Hal itu disebabkan antara lain : masalah manajemen pendidikan yang kurang tepat, penempatan tenaga yang tidak sesuai dengan bidang keahliannya (termasuk di dalamnya pengangkatan kepala sekolah/madrasah yang kurang professional), kurangnya pemerataan kesempatan dan keterbatasan anggaran yang tersedia, sehingga tujuan pendidikan nasional untuk mencerdaskan kehidupan bangsa melalui peningkatan mutu pada setiap jenis dan jenjang pendidikan belum dapat diwujudkan secara signifikan (Rivai, 2016: 118).

Upaya menjaga mutu pendidikan sulit dilepaskan keterkaitannya dengan manajemen mutu. Dalam manajemen mutu semua fungsi manajemen yang dijalankan oleh para manajer pendidikan di madrasah yang diarahkan agar semua layanan 
pendidikan yang diberikan semaksimal mungkin sesuai atau melebihi harapan dari pelanggan.

Pendidikan yang bermutu, dalam arti menghasilkan lulusan sesuai dengan harapan masyarakat, baik dalam kualitas pribadi, moral, pengetahuan maupun kompetensi kerja menjadi syarat mutlak dalam kehidupan masyarakat global yang terus berkembang saat ini dan yang akan datang. Dalam merealisasikan pendidikan yang bermutu, dituntut penerapan program, mutu yang berfokus pada upaya-upaya penyempurnaan mutu seluruh komponen dan kegiatan pendidikan.

Penjaminan mutu dalam dunia pendidikan, memang harus ditingkatkan mengingat mutu pendidikan di Indonesia pada khusuusnya jauh dari apa yang diharapkan. Kita juga mengakui bahwa sekolah-sekolah baik dari tingkat menengah maupun tingkat atas tentang kondisi sarana prasarana dan proses pembelajaran masih kurang memuaskan, sehingga penjaminan mutu pendidikan merupakan program yang utama bahkan amat sangat penting bagi menteri pedidikan dan tentunya bagi pemerintah.

Penjaminan mutu pendidikan itu sendiri merupakan kegiatan mandiri oleh lembaga pendidikan tertentu, oleh karena itu harus disusun, diranacang, dan dilaksanakan sendiri. Salah satu upaya dalam merealisasikan penjaminan mutu tersebut dapat dilakuakan secara bertahap oleh pihak madrasah, yakni dengan melakaukan evaluasi diri, kemudian ditindaklanjuti dengan monitoring madrasah oleh pihak pemerintah daerah, sehingga penjaminan mutu pendidikan dapat dilakukan dengan baik.

Madrasah menggunakan sistem penjaminan mutu yang beragam yaitu antara eksternal, yakni Badan Akreditasi Nasional Sekolah/ Madrasah dan internal. Hal ini berdasarkan hasil survey bahwa sesuai dengan peraturan pemerintah setiap madrasah harus diakreditasi sehingga harus menggunakan BAN-S/M (Badan Akreditasi Nasional Sekolah/Madrasah). Model akreditasi BAN-S/M oleh komunitas madrasah dinilai sebagai sistem yang akan menjamin mutu madrasah.

Badan Akreditasi Provinsi Sekolah/Madrasah yang selanjutnya disebut BANS/M adalah badan evaluasi mandiri yang menetapkan kelayakan program dan/atau satuan pendidikan jenjang pendidikan dasar dan menengah jalur formal dengan mengacu pada standart nasional. 
BAN-S/M mempunyai tugas merumuskan kebijakan operasional, melakukan sosialisasi kebijakan, dan melaksanakan akreditasi Sekolah/Madrasah. BANS/M mempunyai fungsi untuk:

a. merumuskan kebijakan dan menetapkan akreditasi sekolah/ madrasah

b. merumuskan kriteria dan perangkat akreditasi sekolah/madrasah untuk diusulkan kepada Menteri

c. melaksanakan sosialisasi kebijakan, kriteria, dan perangkat akreditasi sekolah/madrasah

d. melaksanakan akreditasi sekolah/madrasah

e. mengevaluasi pelaksanaan dan hasil akreditasi sekolah/madrasah

f. memberikan rekomendasi tentang tindak lanjut hasil akreditasi

g. mengumumkan hasil akreditasi sekolah/madrasah secara nasional

h. melaporkan hasil akreditasi sekolah/madrasah kepada Menteri

i. melaksanakan ketatausahaan BAN-S/M.

Secara konseptual, Pemerintah telah menetapkan standar acuan peningkatan mutu pendidikan madrasah. Standar tersebut terdiri dari visi dan misi organisasi, prinsip-prinsip, tujuan, kebijakan mutu, biaya mutu, evaluasi, serta tindak lanjut. Oleh sebab itu, madrasah dituntut melakukan langkah agar terus mampu survive. Langkahlangkah tersebut di antaranya mengembangkan dan menerapkan manajemen pengelolaan madrasah bermutu, yang di dalamnya termasuk perencanaan strategis, sehingga madrasah memiliki daya saing dengan sekolah umum.

Menghadapi globalisasi, madrasah juga dituntut untuk selalu membaca peluang serta meningkatkan mutu. Bagaimana madrasah bisa mempersiapkan lulusan yang memiliki keunggulan kompetitif, mampu memimpin, terlibat dalam pembaharuan dan perbaikan. Jika itu mampu dijelmakan oleh madrasah, maka dia akan menjadi identitas lembaga pendidikan madrasah. Masyarakat sebagai basis madrasah menetapkan ekspektasi besar terhadapnya. Selain menggarap ranah intelektualitas, pada saat yang sama, aspek moralitas merupakan hal yang dilekatkan pada peran dan fungsi madrasah sebagai lembaga pendidikan yang dibangun di atas susunan nilai-nilai Islam.

\section{Peningkatan Mutu Pendidikan di Madrasah}

Seluruh manajemen komponen pendidikan harus senantiasa berorientasi pada peningkatan dan pencapaian mutu. Semua program dan kegiatan pendidikan serta pembelajaran di lembaga pendidikan, termasuk madrasah pada hakikatnya harus 
dapat diarahkan pada pencapaian mutu. Permasalahan mutu di dalam lembaga pendidikan Islam (madrasah) merupakan permasalahan yang paling serius dan kompleks. Maka, perlu dikerahkan semua pikiran, tenaga, dan strategi untuk mewujudkan mutu pendidikan tersebut.

Berbagai upaya telah dilakukan oleh pengelola lembaga pendidikan Islam (madrasah) dalam rangka meningkatkan mutu pendidikan di lembaganya melalui berbagai cara, metode, pendekatan, strategi, dan kebijakan. Dalam hal perbaikan mutu, diperlukan evaluasi dan analisis hasil evaluasi bersama secara rutin dan berkesinambungan. Berbagai kekurangan secepatnya diperbaiki dan selanjutnya fungsi manajerial hendaknya benar-benar diterapkan dengan baik.

Disinyalir oleh laporan Bank Dunia bahwa salah satu penyebab makin menurunnya mutu pendidikan persekolahan di Indonesia adalah kurang profesionalnya para kepala sekolah sebagai manajer pendidikan di tingkat lapangan (Mulyasa, 2002: 12). Sinyalemen ini meskipun perlu pembuktian lebih lanjut, agaknya memang benar karena kepala sekolah sebagai pengendali, adalah figur yang bertanggung jawab untuk menggerakkan kesadaran semua pihak di lingkungan sekolah, strategi pembelajaran, pengondisian lingkungan belajar dan sebagainya. Ketika unsur-unsur tersebut tidak berkembang, maka biasanya kepala sekolah yang disalahkan, walaupun sebenarnya merupakan tanggung jawab bersama.

Semua pihak yang terlibat dalam lembaga pendidikan, termasuk madrasah memang harus proaktif mendukung terwujudnya mutu pendidikan, kendati peran paling besar dimainkan oleh kepala sekolah/madrasah. Tetapi peranan tersebut tidak dapat fungsional bila tidak didukung oleh semua pihak. Bila pihak-pihak lain tidak merespon ajakan kepala sekolah, maka ibarat bertepuk sebelah tangan. Artinya, memang harus ada timbal balik, atau interaksi antara kepala sekolah sebagai manajer dengan bawahannya untuk bergerak bersama-sama secara sinergis dalam mewujudkan mutu pendidikan.

Pimpinan lembaga pendidikan Islam (madrasah) harus dapat membaca kecenderungan masyarakat ke depan, kemudian merancang strategi baru terkait dengan penjaminan mutu pendidikan. Perbaikan mutu pendidikan, harus diiringi dengan penataan kelembagaan dengan manajemen yang efektif dan efisien. Oleh karena itu, setiap pemimpin pendidikan dituntut mampu mengelola lembaga pendidikannya dengan baik sehingga dapat menjadi lembaga pendidikan yang maju 
dan bermutu. Lembaga pendidikan yang maju dan bermutu akan mampu berkembang dengan baik dan dapat menghasilkan output yang berkualitas.

Mutu pendidikan yang dimaksudkan di sini adalah kemampuan lembaga pendidikan Islam (madrasah) dalam mendayagunakan sumber-sumber pendidikan untuk meningkatkan kemampuan belajar seoptimal mungkin. Dalam konteks pendidikan, menurut Departemen Pendidikan, pengertian mutu mencakup input, proses dan output pendidikan (Wahjosumidjo, 2002: 82). Madrasah yang memiliki mutu baik, tentu akan menjadi salah satu tool untuk mempercepat meningkatnya kualitas pendidikan di Indonesia. Madrasah yang berkualitas akan menghasilkan lulusan (output) yang memiliki daya saing tinggi, mampu berkompetisi di dunia global, yang pada akhirnya akan menjadi salah satu tolok ukur kemajuan suatu bangsa.

Pengkajian dan penelitian tentang efektivitas sekolah dan perbaikan sekolah di beberapa negara menunjukkan bahwa mutu kepemimpinan dan manajemen merupakan salah satu variabel terpenting untuk membedakan antara sekolah yang bermutu atau tidak bermutu (Mutohar, 2016:290). Temuan ini menunjukkan bahwa manajemen tidak bisa dianggap sebagai suatu aspek institusi pendidikan yang jumud dan tidak bisa diubah. Manajemen yang baik akan membuat sebuah perbedaan mutu sekolah/madrasah serta kualitas proses pendidikan yang ada di dalamnya. Hal ini menunjukkan bahwa kompetensi manajerial yang baik harus dimiliki oleh kepala sekolah/madrasah dalam upaya peningkatan mutu pendidikan.

Hasil pendidikan dipandang bermutu jika mampu melahirkan keunggulan akademik maupun non akademik. Keunggulan-keunggulan inilah yang harus dijadikan fokus peningkatan mutu pendidikan di madrasah. Untuk menciptakan keunggulan tersebut diperlukan kemampuan kepala sekolah/madrasah dalam mengelola sekolah/madrasah dengan fokus peningkatan mutu secara berkelanjutan. Manajemen peningkatan mutu madrasah merupakan kompetensi yang harus dimiliki oleh kepala madrasah dalam mengelola peningkatan mutu madrasahnya.

Peningkatan mutu madrasah merupakan tuntutan yang harus direspons secara positif. Madrasah yang merespons secara cepat akan lebih cepat pula mampu memperbaiki kinerja sekolah yang berimplikasi pada peningkatan mutu pendidikannya. Peningkatan mutu pendidikan di madrasah harus diawali dengan niat untuk meningkatkan mutu pendidikan oleh kepala madrasah dan seluruh civitasnya. Niat yang tulus dan baik dalam meningkatkan mutu pendidikan akan menjadikan 
wujud komitmen bersama untuk memperbaiki mutu madrasah. Mutu madrasah tidak akan pernah terwujud jika tidak dibangun komitmen bersama dalam memperbaiki mutu madrasah secara terus menerus yang berorientasi pada mutu pendidikan.

Perbaikan mutu adalah proses yang harus dijalankan secara terus menerus, dan tidak ada kata berhenti untuk berupaya meningkatkan mutu pendidikan madrasah. Oleh karena itu, komitmen mutu yang dibangun di madrasah tidak akan bisa berjalan dengan baik atau dapat meningkat secara terus menerus apabila tidak disertai dengan koordinasi mutu yang secara rutin diselenggarakan oleh madrasah.

Lembaga pendidikan Islam (madrasah) ke depan perlu memiliki sistem yang kuat untuk menjamin mutu yang dapat dipertanggungjawabkan kepada stakeholders. Dengan demikian, perlu ada keseimbangan sistem penjaminan mutu antara internal dan eksternal yang secara bertahap akan mencapai mutu secara komprehensif yang memiliki relevansi dengan perkembangan kebutuhan stakeholders.

\section{SIMPULAN}

1. Selama ini madrasah dianggap sebagai lembaga pendidikan Islam yang mutunya lebih rendah daripada mutu lembaga pendidikan lainnya, terutama sekolah umum, walaupun beberapa madrasah justru lebih maju daripada sekolah umum. Namun keberhasilan beberapa madrasah dalam jumlah yang terbatas itu belum mampu menghapus kesan negatif "sekolah mutu rendah" yang sudah terlanjur melekat selama ini.

2. Upaya peningkatan mutu pendidikan di lembaga pendidikan Islam (Madrasah) dapat dilakukan dengan memperkuat sistem penjaminan mutu pendidikan di madrasah yang antara lain melalui penataan kelembagaan dengan manajemen yang efektif dan efisien, peningkatan kompetensi manajerial kepala madrasah, peningkatan kualitas proses pembelajaran dan penyediaan sarana dan prasarana pendidikan yang memadai.

3. Madrasah perlu memiliki sistem yang kuat untuk menjamin mutu yang dapat dipertanggungjawabkan kepada stakeholders. Sistem penjaminan mutu pendidikan berperan dalam meningkatkan mutu pendidikan di Madrasah. Dengan demikian, perlu ada keseimbangan sistem penjaminan mutu antara internal dan eksternal yang secara bertahap akan mengantarkan madrasah menjadi lembaga pendidikan bermutu sebagaimana lembaga-lembaga pendidikan yang lain. 


\section{DAFTAR PUSTAKA}

Hidayah, Nurul. 2016. Kepemimpinan Visioner Kepala Sekolah dalam Meningkatkan Mutu Pendidikan. Yogyakarta : Ar-Ruzz Media.

Kompilasi Perundangan Bidang Pendidikan. 2009. Yogyakarta: Pustaka Yustisia.

Mahmud, Marzuki. 2012. Manajemen Mutu Perguruan Tinggi. Jakarta : Rajawali Pers.

Makmur, Jamal. 2013. Kiat Melahirkan Madrasah Unggulan. Yogyakarta: DIVA Press.

Makbuloh, Deden. 2016. Pendidikan Islam dan Sistem Penjaminan Mutu. Jakarta : Rajawali Pers.

Mulyasa, E. 2002. Manajemen Berbasis Sekolah: Konsep, Strategi, dan Implementasi. Bandung: PT. Remaja Rosdakarya.

2012. Manajemen \& Kepemimpinan Kepala Sekolah. Jakarta : PT. Bumi Aksara.

Mutohar, Prim. 2016. Manajemen Mutu Sekolah. Yogyakarta : Ar-Ruzz Media.

Nata, Abuddin. 2012. Sejarah Sosial Intelektual Islam Dan Institusi Pendidikannya. Jakarta: Rajawali Press.

Rivai, Veithzal. 2016. Islamic Quality Education Management. Jakarta : PT. Gramedia Pustaka Utama.

Syukran, Ahmadi. 2010. Pendidikan Madrasah Dimensi Profesional dan Kekinian. Yogyakarta : LaksBang PRESSindo).

Umar, Yusuf. 2016. Manajemen Pendidikan Madrasah Bermutu. Bandung : Refika Aditama.

Undang-Undang Republik Indonesia Nomor 20 Tahun 2003 tentang Sistem Pendidikan Nasional. 2006. Bandung: Citra Umbara.

Qomar, Mujamil. 2009. Manajemen Pendidikan Islam. Jakarta : Erlangga.

Wahjosumidjo. 2002. Kepemimpinan Kepala Sekolah Tinjauan Teoritik dan Permasalahannya. Jakarta: PT. Raja Grafindo Persada. 